Volume 7, Nomor 1, Mei 2021. p-ISSN : 2460-9587

e-ISSN : 2614-7017

\title{
PENGEMBANGAN PERANGKAT PEMBELAJARAN MODEL INKUIRI TERBIMBING PADA MATERI ALAT-ALAT OPTIK UNTUK MENINGKATKAN PENGUASAAN KONSEP FISIKA
}

\author{
Yunara Nurmaya1), Susilawati'1), Muhammad Zuhdi'1), Hikmawati' \\ 1)Program Studi Pendidikan Fisika, FKIP, Universitas Mataram, Mataram, NTB, Indonesia \\ Corresponding author : Yunara Nurmaya \\ Email: yunaranurmaya09@gmail.com
}

Diterima 08 Januari 2021, Direvisi 26 Februari 2021, Disetujui 27 Februari 2021

\begin{abstract}
ABSTRAK
Perangkat pembelajaran merupakan bagian terpenting dalam proses pembelajaran, dimana proses pembelajaran berjalan efisien, efektif dan juga terstruktur karena adanya perangkat pembelajaran. Perangkat pembelajaran yang dikembangkan berupa perangkat pembelajaran model inkuiri terbimbing yang terdiri dari silabus, RPP, LKPD, instrument tes penguasaan konsep. Tujuan penelitian ini yaitu untuk mengembangkan perangkat pembelajaran fisika yang valid, efektif, dan efisien dengan menggunakan model inkuiri terbimbing pada materi alat-alat optik untuk meningkatkan penguasaan konsep. Penelitian ini menggunakan jenis penelitian Research and Development (R\&D) dengan model 4D yang terdiri dari empat tahapan yaitu Define, Design, Develop, dan Disseminate. Perangkat yang dikembangkan pada penelitian ini adalah silabus, RPP, LKPD, dan instrumen tes penguasaan konsep. Kevalidan perangkat yang dikembangkan diperoleh berdasarkan penilaian angket dari enam validator yaitu tiga validator ahli dan tiga validator praktisi, kemudian kevalidan perangkat dianalisis dengan menggunakan skala Likert. Keefektifan perangkat diperoleh berdasarkan analisis lembar observasi keterlaksanaan RPP dari tiga orang observer yang kemudian ditentukan dengan menggunakan perhitungan Interjudge Agreement (IJA) dan perolehan nilai $\mathrm{N}$-Gain. Selanjutnya, keefisienan perangkat didapatkan dari hasil uji coba terbatas pada peserta didik kelas XI yang kemudian ditentukan dari respon guru dan peserta didik. Maka dapat disimpulkan perangkat pembelajaran yang dikembangkan efektif. Terakhir, dari respon guru dan peserta didik didapatkan beberapa kendala dari pembelajaran yang telah dilakukan sehingga perangkat pembelajaran model inkuiri terbimbing kurang efisien untuk digunakan dalam pembelajaran.
\end{abstract}

Kata Kunci : perangkat pembelajaran; inkuiri terimbing; penguasaan konsep

\begin{abstract}
Learning tools are the most important part of the learning process, where the learning process runs efficiently, effectively and is structured because of the learning tools. The learning tools developed are in the form of guided inquiry learning models which are based on the syllabus, lesson plans, student worksheet, and concept mastery test instruments. The purpose of this research is to develop valid, effective, and efficient physics learning tools by using guided inquiry models on the material of optical tools to improve concept mastery. This study uses a Research and Development (R\&D) type of research with a 4D model consisting of four stages, namely Define, Design, Develop, and Disseminate. The tools developed in this study were the syllabus, lesson plans, student worksheet, and concept mastery test instruments. The validity of the developed device was obtained based on a questionnaire assessment of six validators, namely three expert validators and three practitioner validators, then the validity of the devices was analyzed using a Likert scale. The effectiveness of the device was obtained based on the analysis of the RPP implementation observation sheet from three observers which was then determined using the calculation of the Interjudge Agreement (IJA) and the acquisition of the $\mathrm{N}$-Gain value. Furthermore, the efficiency of the device was obtained from the limited trial results for class XI students which was then determined from the responses of the teacher and students. So it can be concluded that the learning tools developed are effective. Finally, from the responses of teachers and students, there are several obstacles from the learning that has been done so that the guided inquiry learning model is less efficient for use in learning.
\end{abstract}

Key Word : Learning tools; guided inquiry learning; mastery of concepts 


\section{PENDAHULUAN}

Pendidikan memegang peranan penting untuk kemajuan suatu bangsa. Model atau metode pembelajaran dalam lingkup pendidikan merupakan salah satu faktor yang berpengaruh dalam proses pembelajaran. Hal ini menuntut guru untuk selalu menciptakan proses pembelajaran yang kreatif, inovatif serta menyenangkan sehingga membuat peserta didik termotivasi dalam mengikuti proses pembelajaran. Pembelajaran dikatakan berhasil jika tujuan dari pembelajaran tersebut tercapai. Pembelajaran akan lebih bermakna apabila peserta didik mampu memperoleh suatu pengetahuan secara utuh dengan menghubungkan konsep-konsep yang dipelajari, sehingga konsep yang diperoleh saat pembelajaran dapat diterima dengan baik dan tidak mudah dilupakan (Kosasih \& Sumarna, 2014)

Pembelajaran fisika di SMAN 1 Lingsar masih didominasi menggunakan metode diskusi, tanya jawab dan ceramah serta perangkat pembelajaran yang tersedia dan digunakan oleh guru dari tahun ke tahun hampir sama sehingga hanya mendukung guru untuk menerapkan metode diskusi, tanya jawab dan ceramah yang dominan selama pembelajaran fisika di kelas. Faktor yang menyebabkan peserta didik tidak menyukai pelajaran fisika yaitu, guru terlalu cepat dalam memberi penjelasan dan metode mengajar guru yang cenderung monoton yang menyebabkan peserta didik merasa bosan, dan faktor lainnya yaitu guru kurang memperhatikan kondisi peserta didik yang memiliki kemampuan berbeda-beda dalam memahami materi. Kondisi ini tentu berdampak pada kualitas pemahaman peserta didik terhadap materi yang disampaikan Pemahaman teori yang lemah yang dialami peserta didik tentu memberi dampak yang tidak baik pada pembelajaran peserta didik selanjutnya. Hal tersebut dapat dilandasi oleh dua faktor, meliputi faktor eksternal dan faktor internal. Faktor eksternal adalah faktor yang berasal dari luar, faktor ini meliputi guru, model pembelajaran, fasilitas sekolah, keluarga, teman, dan waktu belajar peserta didik. Faktor internal adalah faktor yang berasal dari dalam diri peserta didik dapat meliputi kondisi fisik, sikap, kemampuan dan motivasi belajar peserta didik.

Di samping itu, kondisi pandemi Covid-19 yang terjadi saat ini pemerintah memutuskan untuk memindahkan proses pembelajaran dari sekolah menjadi pembelajaran di rumah. Peralihan cara pembelajaran ini memaksa berbagai pihak untuk memanfaatkan teknologi sebagai alternatif media pembelajaran daring. Kondisi pandemi Covid-19 yang terjadi saat ini mengharuskan peserta didik belajar melalui sistem daring, keterbatasan akses internet dalam pembelajaran daring akan menyebabkan peserta didik tidak menerima pembelajaran dengan sepenuhnya, apabila peserta didik tidak memahami materi yang diajarkan oleh guru, hal ini akan berdampak pada pemahaman materimateri yang akan disampaikan pada pertemuan selanjutnya. Beranjak dari permasalahan tersebut, perlu adanya suatu upaya dan inovasi pembelajaran yang membantu peserta didik untuk menguasai konsep dalam kegiatan pembelajaran.

Penguasaan konsep fisika sangat penting, karena hanya dengan penguasaan konsep fisika seluruh permasalahan fisika dapat dipecahkan, baik permasalahan dalam kehidupan sehari-hari maupun permasalahan dalam bentuk soal di sekolah (Putri et al., 2018). Penguasaan konsep diartikan sebagai suatu pemahaman dengan menggunakan konsep, kaidah dan prinsip. Dahar (2006) mendefinisikan penguasaan konsep sebagai kemampuan peserta didik dalam memahami makna secara ilmiah baik teori maupun penerapannya dalam kehidupan seharihari. Penguasaan konsep adalah usaha yang harus dilakukan oleh peserta didik dalam merekam dan mentransfer kembali sejumlah informasi dari suatu materi pelajaran tertentu yang dapat dipergunakan dalam memecahkan masalah, menganalisa, menginterpetasikan pada suatu kejadian tertentu (Kusdiastuti et al., 2016).

Berdasarkan berbagai permasalahan yang dihadapi, peneliti berpendapat bahwa perlu ada perubahan dalam penelitian, oleh karena itu peneliti memilih menggunakan penelitian berbentuk pengembangan dengan melihat kepantasan perangkat pembelajaran yang digunakan sehingga penelitian dapat dilanjutkan. Penelitian pengembangan perangkat pembelajaran yang dilakukan berbasis model pembelajaran aktif, menumbuhkan penguasaan konsep dan menciptakan lingkungan belajar menyenangkan, salah satunya yaitu model pembelajaran inkuiri terbimbing. Model pembelajaran akan menentukan keefektifan suatu pembelajaran.

Model pembelajaran inkuiri terbimbing merupakan model pembelajaran yang menekankan pada proses berpikir kritis untuk mencari dan menemukan sendiri jawaban dari suatu masalah yang dipertanyakan, diharapkan dengan mencari dan menemukan pengetahuan sendiri peserta didik lebihemahami konsep- 
konsep melalui percobaan yang ada di dalam materi. Model inkuiri terbimbing merupakan model yang mempersiapkan peserta didik pada situasi untuk melakukan eksperimen sendiri secara luas agar melihat apa yang terjadi, dengan menggunakan model pembelajaran inkuiri terbimbing peserta didik akan mampu menguasai konsep fisika karena pada penerapannya model inkuiri terbimbing menuntut peserta didik untuk menemukan sendiri jawaban dari pertanyaan yang dihadapi. Penerapan model inkuiri terbimbing dalam perangkat pembelajaran fisika diharapkan dapat meningkatkan penguasaan konsep peserta didik dalam kegiatan pembelajaran

Beberapa penelitian sebelumnya terkait pengembangan perangkat pembelajaran model inkuiri terbimbing membuktikan bahwa dengan pembelajaran inkuiri terbimbing peserta didik lebih memahami konsep fisika peserta didik dalam kehidupan sehari-hari. Berdasarkan penelitian yang dilakukan oleh Kurniati et al. (2014), menyimpulkan bahwa pembelajaran menggunakan inkuiri terbimbing berpengaruh terhadap hasil belajar ranah kognitif. Pembelajaran inkuiri terbimbing memiliki beberapa tahapan yaitu menyajikan pertanyaan atau masalah, membuat hipotesis, merancang percobaan, melakukan percobaan, mengumpulkan dan menganalisis data serta membuat kesimpulan.

Perangkat pembelajaran merupakan bagian terpenting dalam proses pembelajaran, dimana proses pembelajaran berjalan secara efisien, efektif dan juga terstruktur karena adanya perangkat pembelajaran. Selain itu, perangkat pembelajaran merupakan perlengkapan seorang guru dalam melakukan proses pembelajaran. Perangkat pembelajaran adalah alat atau perlengkapan untuk melaksanakan proses yang memungkinkan pendidik dan peserta didik melakukan kegiatan pembelajaran. Proses pembelajaran berlangsung lebih terarah dan terstruktur dengan adanya perangkat pembelajaran. Menurut Trianto (2011), dalam pemgembangan perangkat pembelajaran terdapat sepuluh unsur rencana perancangan pembelajaran, yaitu identifikasi masalah, analisis peserta didik, analisis tugas, perumusan indikator, penyusunan evaluasi, strategi pembelajaran, media atau sumber belajar, merinci pelayanan penunjang, menyiapkan evaluasi hasil belajar, dan revisi perangkat pembelajaran.

\section{METODE PENELITIAN Jenis Penelitian}

Penelitian ini menggunakan metode penelitian dan pengembangan Research and Development. Penelitian pengembangan ini dimaksudkan untuk mengembangkan perangkat pembelajaran model inkuiri terbimbing pada materi alat-alat optik untuk meningkatkan penguasaan konsep fisika. Desain penelitian yang digunakan adalah desain model pengembangan $4 D$ yang terdiri atas 4 tahapan yaitu: (1) Define (pendefinisian); (2) Desain (perancangan); (3) Develop (pengembangan); Desseminate (penyebarluasan). Dalam penelitian ini yang menjadi subjek penelitian yaitu peserta didik kelas XI IPA 1 tahun ajaran 2020/2021 SMAN 1 Lingsar.

\section{Teknik Analisis Data}

\section{Analisis Validitas Perangkat Pembelajaran}

Teknik analisis data yang digunakan untuk mengukur kevalidan pengembangan perangkat pembelajaran model inkuiri terbimbing yang dibuat oleh peneliti seperti silabus, RPP, LKPD dan instrument tes penguasaan konsep adalah dengan menggunakan perhitungan skala Likert. Kevalidan dari instrument dikategorikan menjadi beberapa tingkat kevalidan yang ditunjukkan pada Tabel 1 berikut:

Tabel 1. Tingkat Kevalidan Perangkat Pembelajaran

\begin{tabular}{ccc}
\hline $\begin{array}{c}\text { Skor } \\
\text { Penilaian }\end{array}$ & $\begin{array}{c}\text { Rerata } \\
\text { Skor }\end{array}$ & Klasifikasi \\
\hline 4 & $3,26-4,00$ & Sangat Baik \\
\hline 3 & $2,51-3,25$ & Baik \\
\hline 2 & $1,76-2,50$ & Kurang Baik \\
\hline 1 & $1,01-1,75$ & Tidak Baik \\
\hline \multicolumn{3}{c}{ (Susdarwati et al., 2016) } \\
Analisis Keterlaksanaan & RPP & $\begin{array}{c}\text { dalam } \\
\text { Pembelajaran }\end{array}$
\end{tabular}

Penggunaan analisis keterlasaan RPP dalam pembelajaran bertujuan untuk mengetahui keterlaksanaan dan kerunutan RPP yang dibuat. Penentuan nilai analisis ini dilihat dari perolehan skor oleh observer, yang kemudian dianalisis dengan menggunakan persamaan Interjudge Agreement (IJA) berikut;

Keterangan:

$$
I J A=\frac{A_{y}}{A_{y}+A_{N}} \times 100 \%
$$

$A_{y}=$ kegiatan yang terlaksana

$A_{N}=$ kegiatan yang tidak terlaksana

RPP dikategorikan layak digunakan apabila keterlaksanaan pembelajaran mencapai $\geq 75 \%$ (Arsanty \& Wiyatmo, 2017). 
Analisis Peningkatan Penguasaan Konsep Peserta Didik

Peningkatan penguasaan konsep peserta didik dapat ditentukan dengan menggunakan Standar Gain dengan persamaan berikut:

Keterangan :

$$
\text { Std }<g>=\frac{\bar{X}_{\text {sesudah }}-\bar{X}_{\text {sebelum }}}{\bar{X}_{\text {maks }}-\bar{X}_{\text {sebelum }}}
$$

$\bar{X}_{\text {sesudah }}:$ skor post-test

$\bar{X}_{\text {sebelum }}$ : skor pre-test

$\bar{X}_{\text {maks }}:$ skor maksimum 100

\section{HASIL DAN PEMBAHASAN}

Hasil penelitian dan penembangan ini adalah produk berupa perangkat pembelajaran model inkuiri terbimbing pada materi alat-alat optik seperti silabus, RPP, LKPD dan instrument tes. Tahapan yang dilakukan pada penelitian dan pengembangan ini yaitu 1) Define (Pendefinisian), 2) Design (peranccangan), 3) Develop (pengembangan) dan 4) Desseminate (penyebarluasan).

\section{Tahap Pendefinisian (Define)}

Pendefinisian merupakan tahap awal penelitian yang bertujuan mendapatkan informasi mengenasi permasalahan yang muncul pada pembelajaran, metode yang digunakan guru, dan media penunjang yang membantu guru dalam pembelajaran. Analisis awal merupakan kegiatan yang dilakukan untuk mengetahui bagaimana gambaran saat pembelajaran berlangsung. Analisis tugas adalah kumpulan prosedur untuk menentukan isi dalam suatu pembelajaran dengan merinci tugas isi materi ajar secara garis besar dari Kompotensi Inti (KI) dan Kompetensi Dasar (KD) sesuai dengan Kurikulum 2013. Spesifikasi tujuan pembelajaran yaitu perumusan tujuan pembelajaran yang didasarkan pada KI dan KD.

\section{Tahap Perancangan (Design)}

Pada tahap ini dilakukan perancangan pembuatan perangkat pembelajaran yang dikembangkan. Pada tahap perancangan sendiri dilakukan empat langkah perancangan, yaitu penyusunan rancangan silabus, RPP, LKPD, dan instrumen tes penguasaan konsep.

\section{Tahap Pengembangan (Develop)}

Tahap pengembangan merupakan tahapan dalam menghasilkan produk yang dikembangkan. Pada tahap pengembangan, dilakukan beberapa langkah yang dimulai dengan validasi atau penilaian oleh ahli dan praktisi terkait dengan perangkat yang dikembangkan kemudian dilanjutkan dengan uji coba perangkat yang dilakukan secara terbatas, dan terakhir dilakukan penilaian oleh beberapa observer tarkait dengan keterlaksanaan RPP yang dibuat. Uji coba pengembangan perangkat pada penelitian ini dilakukan di SMAN 1 Lingsar dengan melibatkan peserta didik kelas XI MIA 1 sebanyak 15 peserta didik. Berdasarkan hasil uji coba tersebut kemudian didapatkan produk akhir dari perangkat pembelajaran yang dikembangkan. Berikut merupakan penjabaran hasil penilaian berdasarkan lembar validasi, lembar observasi, dan soal tes penguasaan konsep.

\section{Silabus}

Berdasarkan perhitungan menggunakan skala Likert, hasil penilaian rata-rata pada lembar validasi silabus oleh validator ahli adalah 3.56 dengan kategori sangat baik kemudian hasil penilaian rata-rata yang didapatkan dari validator praktisi adalah 3.80 dengan kategori sangat baik.

\section{RPP}

Lembar validasi RPP dengan menggunakan perhitungan skala Likert, didapatkan penilaian rata-rata oleh validator ahli adalah 3.66 dengan kategori sangat baik kemudian hasil penilaian rata-rata yang didapatkan dari validator praktisi adalah 3.83 dengan kategori sangat baik.

\section{LKPD}

Berdasarkan penilaian lembar validasi untuk LKPD dengan menggunakan perhitungan skala Likert, didapatkan penilaian rata-rata oleh validator ahli adalah 3.46 dengan kategori sangat baik kemudian hasil penilaian rata-rata yang didapatkan dari validator praktisi adalah 3.37 dengan kategori sangat baik. Selain itu, dilakukan pula penyebaran angket pada 15 peserta didik kelas XI MIA 1 untuk memberikan penilaian terkait dengan LKPD. Berdasarkan angket tersebut, diperoleh nilai rata-rata dengan perhitungan skala Likert adalah 3.57 dengan kategori sangat baik

\section{Instrumen Tes Penguasaan Konsep}

Lembar validasi untuk intrumen tes penguasaan konsep berdasarkan perhitungan skala Likert, didapatkan penilaian rata-rata oleh validator ahli adalah 3.46 dengan kategori sangat baik kemudian hasil penilaian rata-rata yang didapatkan dari validator praktisi adalah 3.70 dengan kategori sangat baik. Selain itu, dilakukan pula penyebaran angket pada peserta didik kelas XI MIA 1 sebanyak 15 orang untuk memberikan 
penilaian terkait dengan intrumen tes penguasaan konsep dan diperoleh nilai rata-rata dengan perhitungan skala Likert adalah 3.54 dengan kategori sangat baik.

\section{Lembar Observasi}

Lembar observasi digunakan sebagai sarana dalam menentukan kepraktisan atau keterlaksanaan RPP dalam uji coba terbatasa yang dilakukan di SMAN 1 Lingsar pada kelas XI MIA 1. Lembar observer ini diisi oleh tiga observer yang merupakan guru fisika. Analisis perhitungan lembar observasi keterlaksanaan RPP yang digunakan pada penelitian ini adalah dengan persamaan Interjudge Agreement (IJA). Penjabaran persentaser perolehan dari tiga observer dapat dilihat pada Tabel 4.16 di bawah ini.

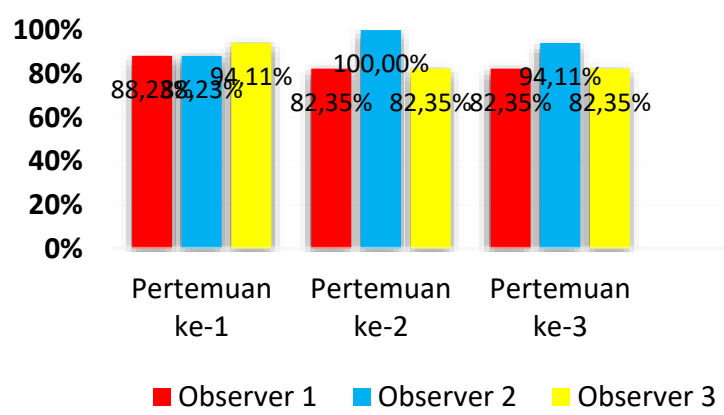

Gambar 1. Diagram Persentase Keterlaksanaan RPP

Berdasarkan Gambar 1, didapatkan rata-rata persentase keterlaksanaan RPP untuk pertemuan pertama adalah $90.19 \%$, kemudian persentase perolehan yang didapat untuk pertemuan kedua adalah $88.23 \%$, dan persentase rata-rata keterlaksanaan RPP pada pertemuan ketiga adalah $86.27 \%$. Rata-rata persentase keterlaksanaan RPP yang didapat dari ketiga observer menunjukkan nilai persentasi $\geq 75 \%$, sehingga dapat dikatakan perangkat yang digunakan sudah baik.

\section{Soal Tes Penguasaan Konsep}

Soal tes penguasaan konsep berupa pretest dan posttest yang digunakan untuk mengetahui peningkatan penguasaan konsep peserta didik XI MIA 1 adalah sebanyak 25 butir soal. Hasil pretest dan posttest ini didapatkan berdasarkan pembelajaran yang telah dilakukan secara terbatas dengan memanfaatkan media online di SMAN 1 Lingsar. Perolehan rata-rata $N$ -
Gain untuk seluruh peserta didik kelas XI MIA 1 yang berjumlah 15 orang adalah 0.47 yang masuk dalam kategori sedang, dengan rincian 3 orang masuk ke dalam kategori tinggi, 8 orang dalam kategori sedang, dan 4 orang pada kategori rendah. Sehingga dapat dikatakan terdapat peningkatan pengusaan konsep peserta didik meskipun tidak terlihat signifikan. Berikut rangkuman peningkatan penguasaan konsep dengan menggunakan uji $\mathrm{N}$-Gain.

Tabel 2. Perolehan Rata-Rata Penguasaan Konsep dengan uji $\mathrm{N}$-Gain

\begin{tabular}{ccccc}
\hline $\bar{X}$ Pre & $\bar{X}$ Post & $\overline{\bar{X}}$ Pre - & $\mathbf{1 0 0}-$ & N-Gain \\
\hline 60.26 & 76.73 & 18.93 & 39.73 & 0.47 \\
\hline
\end{tabular}

Tabel 3. Spesifikasi Ketegori Penguasaan Konsep dengan uji $\mathrm{N}$-Gain

\begin{tabular}{cccc}
\hline $\begin{array}{c}\text { Skor } \boldsymbol{N}^{-} \\
\text {Gain }\end{array}$ & Kategori & $\begin{array}{c}\text { Jumlah } \\
\text { Peserta } \\
\text { Didik }\end{array}$ & Persentase \\
\hline $0,70<\mathrm{g}<1,00$ & Tinggi & 3 & $20 \%$ \\
$0,30<\mathrm{g}<0,70$ & Sedang & 8 & $53.33 \%$ \\
$0,0<\mathrm{g}<0,30$ & Rendah & 4 & $26.67 \%$ \\
\hline
\end{tabular}

\section{Tanggapan Peserta Didik}

Selain dilakukan penyebaran lembar observasi kepada tiga orang observer, peneliti juga meminta tanggapan dari rangkaian pembelajaran yang telah dilakukan dari peserta didik kelas XI MIA 1. Berdasarkan kegiatan pembelajaran yang berpedoman pada pengembangan perangkat pembelajaran, dengan melibatkan perserta didik kelas XI MIA 1 di SMAN 1 Lingsar, berikut merupakan tanggapan dari beberapa peserta didik kelas XI MIA 1 terkait dengan pelaksanaan pembelajaran beserta tabulasi tanggapan pesert didik

Table 4. Tabulasi Tanggapan Peserta Didik

\begin{tabular}{|c|c|c|}
\hline Tanggapan & $\begin{array}{c}\text { Jumlah } \\
\text { peserta } \\
\text { didik }\end{array}$ & Persentase \\
\hline $\begin{array}{l}\text { Positif (menyukai } \\
\text { pembelajaran dengan } \\
\text { model/metode yang } \\
\text { digunakan, mudah } \\
\text { dalam mengikuti dan } \\
\text { memahami materi } \\
\text { pembalajaran) }\end{array}$ & 4 & $26,67 \%$ \\
\hline $\begin{array}{l}\text { Negative (tidak } \\
\text { menyukai } \\
\text { pembalajaran daring, } \\
\text { mengalami kesulitan } \\
\text { dalam mengikuti dan } \\
\text { memahami materi } \\
\text { pembelajaran) }\end{array}$ & 5 & $33,33 \%$ \\
\hline Tidak ada tanggapan & 6 & $40 \%$ \\
\hline
\end{tabular}


Berdasarkan hasil tabulasi tanggapan peserta didik pada Tabel 4, dapat dikatakan bahwa penerapan perangkat pembelajaran model inkuiri terbimbing kurang efisien untuk digunakan. $\mathrm{Hal}$ tersebut dikarenakan keterbatasan dalam melakukan pembelajaran secara daring, seperti halnya peserta didik kesulitan dalam memahami materi yang disampaikan memalui system daring. Akan tetapi, penerapan perangkat pembelajaran model inkuiri terbimbing berdasarkan keterlaksaan pembelajaran yang dinilai oleh guru memberikan respon positif yang berarti bahwa pembelajaran yang dilakukan sudah baik atau atau dapat dikatakan efisien. Sehingga, dapat dikatakan bahwa pembelajaran yang telah dilakukan melalui uji coba terbatas ini adalah efisien menurut guru tetapi kurang efisien menurut peserta didik dikarenakan adanya beberapa kendala yang dialami peserta didik.

\section{Tahap Penyebarluasan (Dessiminate)}

Tahap disseminate dilakukan dengan uji coba lapangan secara luas, dimana perangkat yang telah melalui uji coba terbatas (dalam hal ini hanya dilakukan pada 1 kelas saja) dan diperoleh draf yang kemudian dilakukan perbaikan lalu perangkat tersebut disebarkan dengan skala yang lebih luas lagi. Tetapi, karena keterbatasan kondisi di tengah pandemi Covid19, maka tahapan penyebarluasan ini tidak dapat dilakukan.

Pengembangan perangakat pembelajaran model inkuiri terbimbing dikembangkan dengan tujuan dapat meningkatkan penguasaan konsep peserta didik, khususnya pada materi alat-alat optik. Pengembangan perangkat yang dibuat terdiri dari silabus, rencana pelaksanaan pembelajaran (RPP), lembar kerja peserta didik (LKPD), serta instrument tes penguasaan konsep. Keempat perangkat pembelajaran tersebut, dinilai dan divalidasi oleh validator, tiga validator ahli dan tiga validator praktisi sebelum dilakukan uji coba secara terbatas di SMAN 1 Lingsar.

\section{Validitas Perangkat Pembelajaran Silabus}

Penilaian silabus dalam hal ini dilakukan oleh validator ahli dan validator praktisi untuk mengetahui kevalidan silabus dengan model inkuiri terbimbing yang dibuat oleh peneliti. Berdasarkan perhitungan dengan menggunakan skala Likert, penilaian yang didapat dari validator ahli dan validator praktisi dapat dilihat pada Tabel
4 bahwa perolehan skor rata-rata yang didapat adalah 3.56 dan 3.80 dimana keduanya masuk dalam kategori sangat baik. Sehingga silabus dengan model ingkuiri terbimbing dapat dikatakan valid digunakan dengan perbaikan yang diberikan oleh validator berupa saran atau komentar.

\section{RPP}

Pengembangan RPP yang dibuat oleh peneliti telah disesuaikan dengan sintak model inkuiri terbimbing. Selain mempertimbangkan isi materi dan tujuan pembelajaran dengan model inkuii terbimbng, pengembangan RPP ini juga disesuaikan dengan metode pembelajaran daring baik bagi pengajar maupun peserta didik. Kevalidan dan kelayakan RPP yang dikembangkan peneliti dinilai (divalidasi) oleh validator ahli maupun validator praktisi sebelum kemudian digunakan. Berdasarkan penilaian yang didapat pada pengembangan RPP, didapat skor rata-rata sebesar 3.66 dari validator ahli perangkat dengan kategori sangat baik dan 3.83 dari validator praktisi dengan kategori sangat baik. Maka, dapat dikatakan pengembangan RPP dengan model inkuiri terbimbing valid dan layak untuk digunakan dengan beberapa masukan yang telah dijabarkan.

\section{LKPD}

Pengembangan LKPD ini sebelumnya divalidasi oleh tiga validator ahli dan tiga validator praktisi. Berdasarkan penilaian yang dilakukan oleh validator ahli dan praktisi yang terkait dengan kevalidan dan kelayakan pengembangan LKPD, didapatkan skor rata-rata dengan menggunakan skala Likert secara berturut-turut adalah 3.46 dan 3.37 dengan kategori sangat baik. Pada LKPD juga dilakukan penilaian oleh 15 peserta didik kelas XI MIA 1 dengan dilakukan penyebaran angket melalui google form, kemudian didapatkan skor rata-rata 3.57 dengan kategori sangat baik. Secara keseluruhan LKPD dapat dikatakan valid dan layak untuk digunakan dengan beberapa revisi yang didapatkan dari saran validator.

\section{Instrument tes penguasaan konsep}

Instrumen tes penguasaan konsep yang dibuat peneliti terdiri dari 25 butir soal pilihan ganda. Insturmen tes penguasaan konsep pada penelitian pengembangan ini digunakan untuk mengukur keefektifan perangkat yang telah dibuat. Sama halnya dengan silabus, RPP, dan LKPD, sebelum digunakan untuk melakukan pengambilan data maka terlebih dahulu 
instrumen tes dinilai kevalidan dan kelayakannya. Berdasarkan validasi oleh validator ahli dimana didapatkan skor rata-rata sebesar 3.46 dengan kategori sangat baik, sedangkan rata-rata yang diperoleh dari validator praktisi adalah 3.54 dengan kategori sangat baik. Secara keseluruhan, maka intrumen tes penguasaan konsep valid dan dapat digunakan dengan beberapa perbaikan. Perbaikan-perbaikan tersebut berkaitan dengan redaksi soal yang dibuat, dimana redaksi maupun gambar pada soal lebih diperjelas agar tidak menimbulkan penafsiran ganda.

\section{Efektivitas Perangkat Pembalajaran}

Efektivitas perangkat pembelajaran pada penelitian ini ditentukan dari persentase keterlaksanaan pembelajaran serta dari hasil $N$ Gain. Keterlaksanaan pembelajaran didapatkan dari angket observasi yang disebarkan kepada tiga orang observer guna mengetahui sejauh mana keterlaksanaan RPP pada uji coba terbatas yang dilakukan di SMAN 1 Lingsar, kelas XI MIA 1. Persentase rata-rata yang didapat dari ketiga observer dengan menggunakan perhitungan Interjudge Agreement (IJA) adalah 90.19\% untuk keterlaksanaan RPP pada pertemuan pertama, $88.23 \%$ untuk pertemuan kedua, dan $86.27 \%$ untuk pertemuan ketiga. Rincian skor IJA dari tiga observer dapat dilihat pada Tabel 4.24. Berdasarkan nilai persentase tersebut, maka keterlaksanaan RPP secara keseluruhan sudah baik karena melebih angka 75\%. Meskipun demikian, terdapat beberapa kendala yang dialami peneliti dalam pelaksanaan pembelajaran pada kelas XI MIA 1 di SMAN 1 Lingsar antara lain, keterbatasan akses internet bagi peserta didik sehingga tidak semua peserta didik dapat ikut serta dalam setiap rangkaian pembelajaran. Kurangnya partisipasi peserta didik dalam menjawab pertanyaan yang diberikan, serta keterbatasan waktu mengajar selama pembelajaran daring dilakukan di SMAN 1 Lingsar, sehingga disini peneliti berinisiatif untuk membuatkan ringkasan materi ajar dan video pembelajaran terakit dengan materi alat-alat optik sebagai salah satu bentuk penguatan kepada peserta didik.

Selain itu, efektivitas perangkat pembelajaran juga dilihat dari peningkatan penguasaan konsep peserta didik yang dilakukan melalui tes tertulis berbentuk pilihan ganda sebanyak 25 butir soal dalam bentuk pretest dan posttest yang kemudian diperoleh nilai $\mathrm{N}$-Gain. Tes dilakukan dengan total waktu 90 menit yang kemudian jawaban peserta didik dapat dikirimkan melaui link google form. Perolehan nilai rata -rata berdasarkan tes yang telah dilakukan untuk pretest adalah 60.26 dengan nilai tertinggi adalah 80 dan nilai terendah adalah 28 sedangkan untuk rata-rata nilai posttest adalah 76.73 dengan nilai tertinggi 96 dan nilai terendah adalah 60 . Selanjutnya, peningkatan pengasaan konsep peserta didik diukur dengan menggunakan persamaan standart gain yang dibagi menjadi tiga ketegori Hasil analisis diperoleh nilai standart gain adalah 0.47 yang berarti masuk ke dalam kategori sedang. Spesifikasi jumlah peserta didik berdasarkan nilai pretest dan posttest terdapat 3 orang masuk dalam kategori tinggi, 8 orang masuk pada kategori sedang, dan 4 orang dalam kategori rendah. Sehingga dapat dikatakan, terdapat peningkatan kemampuan penguasaan konsep peserta didik, meskipun peningkatan tersebut tidak terlalu signifikan karena adanya keterbatasan dalam melakukan pretest maupun posttest yaitu ketersediaan waktu dan akses internet yang beberapa peserta didik yang mengumpulkan melebihi batas waktu yang telah ditentukan.

Maka, berdasarkan persentase keterlaksanaan pembelajaran dan nilai $N$-Gain yang diperoleh, dapat dikatakan pengembangan perangkat pembelajaran model inkuiri terbimbing yang dibuat efektif untuk meningkatkan penguasaan konsep peserta didik dengan persentase keterlaksanaan pembelajaran melebih $75 \%$ dan nilai $N$-Gain masuk dalam ketegori sedang.

\section{Efisiensi Perangkat Pembelajaran}

Efisiensi perangkat pembelajaran ditentukan berdasarkan respon dari peserta didik kelas XI MIA 1 dan respon dari guru terhadap pembelajaran yang telah dilakukan. Tanggapan peserta didik kelas XI MIA 1, dimana sebagian peserta didik merasa kesulitan selama pembelajaran daring, dikarenakan keterbatasan waktu dalam melakukan pembelajaran secara daring, seperti halnya peserta didik kesulitan dalam mengikuti dan memahami materi pembelajaran yang disampaikan melalui system daring. Namun, secara keseluruhan peserta didik masih terbiasa dengan pembelajaran tatap muka sehingga kesulitan ketika pembelajaran dilakukan secara daring. Hal ini sejalan dengan kelemahan model pembelajaran inkuiri terbimbing yang dikemukakan Suryosubroto (2010) yaitu diperlukan kesiapan mental untuk belajar, kurang berhasil dikelas besar, sulit dalam merancang pembelajaran karena terbentur kebisaan peserta didik dalam belajar, dan sulit 
Volume 7, Nomor 1, Mei 2021. p-ISSN : 2460-9587

e-ISSN : 2614-7017

mengontrol kegiatan peserta didik. Berdasarkan hal diatas, dapat dikatakan perangkat pembelajaran yang dikembangkan kurang efesien dilakukan dengan pembelajaran daring.

\section{SIMPULAN DAN SARAN}

Berdasarkan hasil penelitian dan pembahasan, maka dapat dikesimpulkan bahwa: Perangkat pembelajaran model inkuiri terbimbing pada materi alat-alat optik layak digunakan untuk meningkatkan penguasaan konsep peserta didik dengan katagori sangat baik, sehingga dapat digunakan dalam pembelajaran. Perangkat pembelajaran model inkuiri terbimbing pada materi alat-alat optik efektif untuk meningkatkan keterampilan penguasaan konsep peserta didik dengan katagori sedang. Perangkat pembelajaran model inkuiri terbimbing pada materi alat-alat optik untuk meningkatkan penguasaan konsep peserta didik kurang efisien dalam pembelajaran daring. Saran, perlu dilakukan penelitian sejenis dengan menggunakan model inkuiri terbimbing pada materi fisika lainnya guna mengetahui ketepatan model pembelajaran dalam upaya meningkatkan penguasaan konsep peserta didik.

\section{DAFTAR RUJUKAN}

Arsanty, V. N., \& Wiyatmo, Y. (2017). Pengembangan Perangkat Pembelajaran Fisika Berbasis Model Pembelajaran STS dalam Peningkatan Penguasaan Materi dan Pencapaian Kreativitas Peserta Didik SMA. Jurnal Pendidikan Fisika, 6(1), 23-32.

Dahar, R. W. (2006). Teori-Teori Belajar \& Pembelajaran. Erlangga.

Kosasih, N., \& Sumarna, D. (2014). Pembelajaran Quantum dan Optimalisasi Kecerdasan. Bandung : Alfabeta.

Kusdiastuti, M., Harjono, A., Sahidu, H., \& Gunawan, G. (2016). Pengaruh Model Pembelajaran Inkuiri Terbimbing Berbantuan Video Kontekstual Terhadap Penguasaan Konsep Fisika Peserta Didik. Jurnal Pendidikan Fisika Dan Teknologi, 2(3), 116-122. https://doi.org/10.29303/jpft.v5i2.1393

Putri, S. B., Sarwi, \& Akhlis, I. (2018). Pembelajaran Inkuiri Terbimbing Melalui Kegiatan Lab Virtual dan Eksperimen Riil. Unnes Physics Education Journal, 7(1), 1422.

Santi, I. K. L., \& Santosa, R. H. (2016). Pengembangan Perangkat Pembelajaran Menggunakan Pendekatan Saintifik pada Materi Pokok Geometri Ruang SMP.
PYTHAGORAS: Jurnal Pendidikan Matematika, $\quad 11(1), \quad 35$. https://doi.org/10.21831/pg.v11i1.9673

Susdarwati, S., Sarwanto, S., \& Cari, C. (2016). Pengembangan Perangkat Pembelajaran Fisika Berbasis Problem Based Learning (Pbl) Pada Materi Hukum Newton Dan Penerapannya Kelas X Sman 2 Mejayan. INKUIRI: Jurnal Pendidikan IPA, 5(3), 1. https://doi.org/10.20961/inkuiri.v5i3.9434

Trianto. (2011). Mendesain Model Pembelajaran Inovatif-Progresif. Kencana Prenada Media Group. 